\title{
Research on Improving Engineering Quality of College Students
}

\author{
Han Xianlong \\ Engineering Training Center, Beihua University, Jilin, China \\ bhhxl@126.com
}

Keywords: engineering quality; engineering consciousness; college students

\begin{abstract}
In domestic higher education, especially the non engineering students in the face of the engineering problems of lack of knowledge, has been unable to meet the social demand for talents, confined to the engineering majors cannot raise the engineering quality, engineering quality education into science, management, forestry, literature and other disciplines in the field that has a positive effect on improving the overall knowledge structure of College students. Through the engineering practice teaching reform, and Study on the factors and influence engineering quality connotation, explore suitable for the requirements of engineering practice teaching system and mode of cultivating students' engineering quality training, to improve the engineering quality of University students.
\end{abstract}

\section{Introduction}

As a big manufacturing country, China is facing many social problems, such as product quality, production safety and environmental protection, so it is urgent to have a large number of talents with higher engineering quality. College Students' engineering quality training methods and means weak, no engineering quality, most Polytechnic professional disciplines basically training links, so the higher education in college students' engineering quality training are lagging behind the social development and needs, should take timely measures to solve the ways of training, improve the quality of the engineering talents. With the social engineering quality of the pillars of college students to improve and promote the overall national engineering awareness and engineering quality, its social and economic benefits are enormous.

\section{A Review of Higher Engineering Education Research}

The British trial "sandwich" teaching mode in engineering education, the goal of the education is to cultivate talents for the development of local industry and commerce, and in engineering exploration during the internship, evening class education mode. It adopts the "theory practice theory" alternative mode of talent training, emphasizing practice and engineering education. Israeli scholars also put forward that the teaching mode based on engineering design is the best teaching mode in engineering education, and realizes the coordination of education policy and national innovation system. In recent years, American universities have stepped up the reform of engineering education, constructed a multi-level and diversified engineering education system, and established the "return project" talent training mode. The so-called "return project" refers to the mode of higher engineering education by too much emphasis on Engineering Science Quality Education for the students pay more attention to the cultivation of quality and engineering practice in the engineering background of environmental quality, so as to strengthen the engineering practice ability of Engineering College students.

Since 1996, the construction engineering training center in Colleges and universities has opened up the technical training and practical activities of comprehensive engineering in schools. In comprehensive universities, engineering training is no longer confined to engineering students, and students majoring in literature, management, forestry, science and technology have access to engineering practice education. Its purpose is to improve the engineering skills and innovative ability of college students, constantly expand knowledge, and cultivate more comprehensive talents for the society. Its essence is to improve students' overall engineering quality. 
The deficiency of the existing engineering education methods and training modes is that the engineering knowledge, engineering skills, engineering consciousness, engineering innovation ability and other comprehensive engineering quality training can not be organically integrated. Non engineering majors rarely open engineering practice teaching, students face engineering problems show the skill level of the inner quality and the lack of quality engineering; lack of awareness training, lack of goals, methods, means and necessary; independent college students lack of opportunities to practice engineering and the spirit of active learning.

\section{Characteristics of Engineering Technology Practice Education}

Engineering practice education is based on the goal of talent cultivation of higher engineering education of modern engineering technology, with modern technology as the focus, in a practical environment, covering machinery, electronics, information technology and information technology as the core of the automation system, set design and guidance, project planning and organization management as a whole. The engineering practice training to inspire and cultivate students' innovation consciousness and ability to focus on. The characteristics of engineering technology practice education are mainly practical, advanced, comprehensive and interdisciplinary.

The Practicality of Engineering Technology Practice Education. Engineering practice is accomplished through a series of specially designed engineering practices. These include the engineering practice of computer aided product or system design, the use of all kinds of machine parts, using a variety of techniques for measurement, material forming, surface treatment, product components and production process and process analysis and development, and the development of a product or a project planning and completion etc.. Engineering practice teaching methods, teaching materials, students' learning methods and evaluation methods of academic performance should be subject to the practical characteristics of the curriculum.

The Advance of Practical Education of Engineering Technology. The mission of modern higher engineering education is to enable students to have the ability to promote the progress of science and technology after graduation. This requires students in the process of engineering practice training can dabble in some advanced new technology. The advance characteristics of engineering technology practice should be manifested in two interrelated aspects. One is to highlight the modern characteristics and advance in the training content. The goal of modern higher engineering education is to adapt to the requirements of the times, and to promote the social science and technology progress desire and ability of contemporary engineering and technical personnel. Therefore, the higher engineering education should emphasize the advance of the content in the teaching process, including the engineering technology practice, under the premise that the students can get a more generous basic knowledge.

The Comprehensiveness of Engineering Technology Practice Education. The comprehensive practice of engineering technology is manifested in two aspects, one is the comprehensiveness of training content. The content of engineering technology practice involves many categories of engineering technology, such as electronic, electrical, mechanical, hydraulic, pneumatic, information technology, metal materials, non-metallic materials and so on. The training content is the combination of mechanical and electrical, the combination of metal materials and non-metallic materials, the combination of design and manufacture, the combination of computer information technology and many kinds of engineering technology, and the combination of process technology and management. Another meaning of comprehensive is that engineering technology practice is the exercise and training of students' comprehensive ability. Students should learn, be familiar with and participate in project planning, organization and management in the process of engineering practice training, and also learn to communicate and communicate with related personnel. Therefore, the engineering practice has a strong comprehensive, it is the process of training students' comprehensive ability. The practice and training of students' comprehensive ability in engineering technology can not be replaced by other courses.

The Cross Discipline of Engineering Technology Practice Education. In the process of practical training of engineering technology, students will encounter some technical problems 
involving subject edges and cross disciplines, which are often ignored in professional teaching. A lot of practice has proved that these knowledge is very important for technology, product development and solving practical engineering problems. "Rapid prototyping and mold manufacturing" is a typical example of interdisciplinary, this new technology involves computer information science and materials science and mold manufacturing discipline, is a typical interdisciplinary example. Again, metal and nonmetal surface treatment also requires the intersection and integration of chemistry, materials science and electrochemistry, electricity and other disciplines.

\section{Countermeasures to Improve the Engineering Quality of College Students}

Strengthen Individual Engineering Skill Training and Train Students' basic Engineering Practice Ability. Through the completion of the provisions of the training project, focusing on solving individual engineering skills training problems. The theoretical explanation, demonstration and hands-on training, practical assessment and other aspects, group training, training of engineering students' basic skills practice.

Through the Reform of Practice Teaching Mode, Carry out Innovative Training in Class. The project goal, to product development to product life cycle operation as the carrier, to project task driven, to enable students to understand a socially valuable product from concept to design, such as: you can ask the students before practice, equipment, tools etc. according to this course involves hardware facilities, design a has certain function parts or products, and during the internship period to complete the processing and acceptance of production, etc., fully embodies the "learning by doing, learning by doing". This method can make different engineering training projects are effectively combined, can effectively solve the defects in the group, training the students establish the concept of engineering.

Actively Carry out Extracurricular Comprehensive Skills Training to Cultivate College Students' engineering Innovation Ability. In all kinds of science and technology contest activities as the carrier, to the college students' engineering practice of innovative education bases, college students to carry out day-to-day engineering skills, innovation ability and science and technology competitions, training of engineering students' innovative ability and practice ability. Actively organize students to participate in engineering training comprehensive ability competition, mechanical innovation design competition and other activities, stimulate students' Initiative Practice and initiative innovation ability.

Strengthen the Construction of Engineering Culture, Strengthen the Students' engineering Consciousness through the Edification of Environment. Through the development of a variety of engineering panels, such as celebrities in the field of engineering history, mechanical engineering, famous engineering safety warning signs, typical cases, processing cost and environmental protection, through the invisible education method, influence students' engineering sentiment, which makes the engineering education refreshing, internalized in the heart, outside of the line.

Improve the Quality Evaluation System of Engineering Technology Practice Teaching, and Evaluate the Teaching Effect Scientifically. Through strengthening the monitoring of engineering practice teaching process, improving the training evaluation mechanism and performance evaluation method, the teaching quality is analyzed and evaluated with the teaching effect. Including the management, operation and organization of teaching practice teaching methods, practice teaching and training mode, teacher practices and student daily training as the evaluation indexes, constructed the evaluation system of practical PEEa engineering teaching quality, i.e.: PProcess monitoring; E- Evaluation; Ea- Effect analysis 。

\section{Concluding Remarks}

Engineering quality mainly refers to the level of engineering quality, cost, responsibility, safety and environmental awareness, which is based on engineering knowledge and engineering ability. As a big manufacturing country, China is facing many social problems, such as product quality, 
production safety and environmental protection, so it is urgent to have a large number of talents with higher engineering quality. College Students' engineering quality training methods and means weak, no engineering quality, most Polytechnic professional disciplines basically training links, so the higher education in college students' engineering quality training are lagging behind the social development and needs, should take timely measures to solve the ways of training, improve the quality of the engineering talents. With the social engineering quality of the pillars of college students to improve and promote the overall national engineering awareness and engineering quality, its social and economic benefits are enormous.

\section{Acknowledgement}

Foundation project: the key project of Jilin Education Science Planning: Research on the strategy of improving engineering quality of College Students under the background of public project (project number ZD16017)

\section{Reference}

[1] Bergin M .2011, "N Vivo 8 and Consistency in Data Analysis: Reflecting on The Use of A Qualitative Data Analysis Program”, Nm se Researcher, Volume18, Number 3, PP 6-12.

[2] Elaime Welsh, 2002, ”Dealing with Data: Using N Vivo in the Qualitative Data Analysis Process”. FOR UM: Qualitative Social Research, Volume 3,Number 2 Art .26.

[3] Huang Guanhong, 6. System engineering method and application [M]. Guangzhou: Jinan University press, 2005.

[4] Wu steel. Modern education evaluation based on [M]. Shanghai: Science Press, 2004.

[5] Zhao Huanchen. A simple and easy method for decision making in analytic hierarchy process [M]. Beijing: Science Press, 1986. 